\title{
Studi Komparatif Perpajakan dalam Sharing Economy : Studi Kasus Jasa Angkutan Berbasis Online
}

\author{
Bellinda Aurellia ${ }^{1 *}$, Bina Meidiana Sari ${ }^{2}$, Angelin Dena Rony ${ }^{3}$ \\ 1, 2,3 Politeknik Keuangan Negara STAN, Tangerang, Indonesia \\ ${ }^{1}$ bellindaarl@gmail.com, ${ }^{2}$ b.meidianas@ gmail.com , ${ }^{3}$ angeldena71@yahoo.com \\ * corresponding author
}

\section{ARTICLE INFO}

\section{Article history}

Received 2020-02-29

Revised 2020-06-05

Accepted 2020-06-23

Keywords

Tax, Ride-Hailing Services

\begin{abstract}
New innovation and technology that was born together with $4^{\text {th }}$ Industrial revolution triggered the disruption in various aspect of human life. In Indonesia, one of the most prominent disruption is within the transportation industry. The assimilation of technology and conventional transportation method gave birth to various financial technology that provides online-based transportation such as Gojek, Grab, and Uber. China is the country with the highest revenue generated from the industry. In Southeast asia, other than in Indonesia, the industry also growing fast in Singapore, Malaysia, and Vietnam. This research intend to find out the taxation regulation applied to ride-hailing services in the four countries mentioned using literature study. From the research, it can be concluded that China, Singapore, Vietnam, and Malaysia has had taxation regulation for ride-hailing services. Tax collection in Singapore has been working finely with the regulation applied, but problems arise in China, Vietnam, and Malaysia in the terms of tax rate for the drivers and tax rate for the firms because of the drivers and firms ambiguous classification as a tax subject.
\end{abstract}

\section{PENDAHULUAN}

Negara Kesatuan Republik Indonesia adalah negara kesatuan yang telah berdiri selama kurang lebih 75 tahun. Sebagaimana negara lainnya, Indonesia memiliki tujuan yang menjadi hakikat dalam pendiriannya. Tujuan pendirian Indonesia tertuang dalam alinea ke-4 pembukaan UUD 1945 yang berbunyi, “... melindungi segenap bangsa Indonesia dan seluruh tumpah darah Indonesia dan untuk memajukan kesejahteraan umum, mencerdaskan kehidupan bangsa, dan ikut melaksanakan ketertiban dunia yang berdasarkan kemerdekaan, perdamaian abadi dan keadilan sosial...". Salah satu instrumen kebijakan pemerintah untuk mencapai visi kenegaraan adalah Anggaran Pendapatan dan Belanja Negara (APBN), yang mana menjadi sarana pendukung pendanaan berbagai program yang dilaksanakan oleh negara. Sumber pendapatan negara yang memberikan kontribusi terbesar dalam APBN adalah penerimaan pajak yang menyumbang sekitar 83\% dari total penerimaan negara (APBN 2019). Hal ini menunjukkan betapa pentingnya kontribusi perpajakan bagi kelangsungan pembangunan Indonesia.

Namun, saat ini dunia tengah mengalami era Revolusi Industri yang ke-empat, dimana muncul beragam disrupsi yang dibawa oleh inovasi teknologi. Disrupsi ini juga berpengaruh ke pasar tenaga kerja. Van Dam (2017) menyatakan bahwa pasar tenaga kerja akan mengalami perubahan yang signifikan, dimana akan ada banyak lapangan kerja dan jenis profesi yang hilang dan tergantikan dengan lapangan kerja dan jenis profesi yang baru. Otoritas pajak selaku organisasi yang merumuskan dan melaksanakan kebijakan dan standardisasi teknis di bidang perpajakan harus dapat beradaptasi dengan dinamika perubahan lapangan kerja yang terjadi demi meningkatkan efektivitas perpajakan.

Di Indonesia sendiri, inovasi disruptif yang paling menonjol terdapat di bidang transportasi dengan munculnya jasa angkutan berbasis online seperti Grab dan Go-jek yang keberadaannya mulai menggeser posisi jasa transportasi konvensional sebagai pilihan masyarakat. Berdasarkan riset yang 
dilakukan oleh Google, Temasek dan Bain Company tahun 2019 (Dikutip dalam Katadata, 2019), Indonesia menempati posisi pertama pada pangsa pasar layanan transportasi online se-Asia Tenggara tahun 2019 dengan nilai valuasi mencapai US\$ 5,7 miliar dari total nilai valuasi pangsa pasar Asia Tenggara yang sejumlah 12,7 miliar. Besarnya pangsa pasar jasa transportasi online ini di Indonesia memberikan peluang dan tantangan bagi pemerintah Indonesia sendiri. Valuasi yang tinggi memberikan sinyal bahwa terdapat potensi penarikan pajak yang besar dari industri jasa layanan transportasi online. Namun, hal ini juga menjadi tantangan tersendiri bagi pemerintah karena walaupun jasa layanan transportasi online dipandang sebagai bagian dari industri transportasi, jasa layanan transportasi online memiliki argumentasi bahwa core bisnis mereka berbeda dari industri transportasi. Nurhidayah \& Alkarim (2017) dalam risetnya mengutarakan bahwa regulasi yang diterapkan pada jasa transportasi konvensional dianggap tidak dapat diterapkan untuk jasa transportasi online karena tidak mengakomodir kunci bisnis jasa transportasi online, yakni kemajuan teknologi. Hal ini juga berlaku untuk regulasi perpajakan. Belum ada peraturan yang jelas terkait dengan penarikan pajak terhadap jasa transportasi online. Walaupun wacana penarikan pajak sudah beredar selama beberapa tahun terakhir, sampai saat ini perpajakan untuk jasa transportasi online tersebut belum terlaksana (Kumparan,2019). Berdasarkan uraian-uraian diatas, penelitian ini dibuat dengan tujuan memberikan tinjauan aturan-aturan perpajakan yang diterapkan di beberapa negara yang memiliki nilai valuasi tinggi dalam industri jasa transportasi online, khususnya dalam lingkup aturan pajak penghasilan bagi pengemudi dan aturan pajak pertambahan nilai bagi perusahaan jasa transportasi online.

\section{METODE PENELITIAN}

Penelitian ini dilakukan dengan cara menelaah literatur-literatur ilmiah, artikel, undang-undang, dan referensi lainnya yang terkait dengan regulasi perpajakan di Tiongkok, Singapura, Malaysia, dan Vietnam. Penelaahan tersebut akan menghasilkan identifikasi regulasi perpajakan (khususnya pada pajak penghasilan dan pajak pertambahan nilai) yang diterapkan di masing-masing negara dan tantangan yang timbul dalam pelaksanaan regulasi tersebut.

\section{HASIL DAN PEMBAHASAN}

\section{Regulasi Perpajakan Jasa Angkutan Berbasis Online di Beberapa Negara}

\section{China}

\section{a. Gambaran Umum}

China adalah negara dengan penduduk terpadat di dunia sehingga menjadikannya sebagai ladang bisnis yang potensial, tidak terkecuali bagi penyedia jasa transportasi online. Terdapat beberapa penyedia layanan jasa ini, salah satunya Didi Chuxing yang sekarang menguasai industri penyedia jasa transportasi online di China dan merupakan hasil peleburan antara Didi Kuaidi dengan Uber China yang terbentuk pada Agustus 2016. Jasa layanan yang disediakan oleh Didi Chuxing antara lain adalah jasa transportasi, penyewaan mobil pribadi, pengantaran makanan, bahkan akses ke perusahaan pesaing seperti FAW Group, Dongfeng Motor, dan Guangzhou Automobile Group.

Peraturan perpajakan untuk jasa transportasi online di China terbagi menjadi dua, yaitu pajak langsung dan pajak tidak langsung. Pajak langsung dimaksudkan untuk memotong pendapatan driver, sementara pajak tidak langsung ditujukan untuk memotong pendapatan perusahaan. Besarnya pajak yang dikenakan atas jasa transportasi online di China ialah sebesai $3 \%$.

\section{b. Pajak Langsung}

Pajak langsung yang dibebankan pada jasa layanan transportasi online adalah pajak untuk penghasilan yang didapatkan oleh driver. Di China, aturan untuk pekerja tidak menjelaskan hubungan antara perusahaan ride-hailing dan para driver sehingga biasanya perusahaan mengklasifikasikan driver ke beberapa bagian sesuai kebijakan masing-masing. Didi Chuxing sendiri tidak mengklasifikasikan driver sebagai pegawai tetap. Meskipun demikian, perusahaan menahan pemasukan bulanan driver sebagai pajak penghasilan untuk driver, 
namun melaporkannya sebagai pendapatan layanan pribadi karena driver tidak terdaftar sebagai pegawai tetap. Akibatnya, uang tersebut diklasifikasikan sebagai pendapatan kontijensi dan dikenakan pajak atas layanan jasa sebesar $6 \%$, berbeda dari pajak progresif yang biasa dikenakan untuk gaji dan upah pegawai tetap.

c. Pajak Tidak Langsung

Pajak tidak langsung jasa transportasi online di China lebih fokuskan pada cara penarikan pajak tersebut. Peraturan pajak pertambahan nilai sebagai pajak tidak langsung yang dimaksud diatas telah menetapkan semua perjalanan driver Didi Chuxing sebagai objek PPN. PPN dikenakan atas perusahaan, bukan driver secara individual, demi kesederhanaan proses penarikan pajak. Namun Didi kemungkinan telah membuat kesepakatan dengan driver untuk menyesuaikan biaya komisi driver sebagai utang PPN, namun isi kesepakatan ini tidak dibuka untuk publik.

d. Implementasi dan Tantangan

Implementasi peraturan perpajakan atas jasa transportasi online di China dapat dikatakan berjalan dengan baik. Hal ini dapat dilihat dari kenaikan pendapatan pajak berkat PPN yang dibayarkan oleh penyedia jasa layanan transportasi online, termasuk Didi Chuxing. Pemerintah China sangat mengantisipasi PPN dari ride-hailing service ini karena meningkatkan pendapatan PPN sebesar 70.000 yuan menjadi 100.000 yuan, yang apabila dikonversikan dapat menjadikan PPN di China besar daripada PPN di Inggris.

Tantangan yang dihadapi oleh Pemerintah China dalam penerapan peraturan perpajakan atas ride-hailing service ini adalah pemisahan pajak yang dikenakan kepada Didi Chuxing atas layanan transportasi dan layanan jasa yang diberikannya. Pajak sebesar 3\% untuk PPN layanan transportasi dan dihitung menggunakan metode simplifikasi, sedangkan tarif 6\% diberlakukan untuk bisnis layanan jasa.

\section{Singapura}

a. Gambaran Umum

Jasa transportasi online telah masuk ke Singapura sejak beberapa tahun belakangan dan berkembang pesat hingga mulai menyingkirkan jasa transportasi konvensional. Beberapa perusahaan penyedia jasa angkutan berbasis online Singapura diantaranya adalah Grab, Uber, dan Gojek. Namun kini Uber telah diakuisisi oleh Grab dan telah secara resmi berhenti beroperasi di Singapura sejak April 2018. Seperti di negara lain, penyedia layanan transportasi online di negara ini tidak hanya menyediakan jasa angkut tapi juga jasa lainnya seperti pengantaran makanan, pembelian pulsa, pembelian barang-barang di toko grosir, dan masih banyak jasa lainnya yang masih akan terus dikembangkan untuk kemudahan bagi para penggunanya.

Regulasi tentang operasional jasa angkutan berbasis online sendiri mulai dirumuskan pada tahun 2016 seiring dengan pesatnya perkembangan industri ini. Untuk peraturan perpajakan, Singapura memiliki Goods and Services Tax (GST) yang merupakan PPN yang mengatur salah satunya tentang aturan perpajakan untuk para penyedia jasa di era ekonomi digital, termasuk jasa angkutan berbasis online.

b. Pajak Langsung

Pada website resmi salah satu penyedia layanan jasa transoportasi online di Singapura, dijelaskan bahwa driver wajib mengisi form pajak penghasilan yang disediakan oleh perusahaan. Setiap pesanan yang diterima driver melalui aplikasi akan tercatat di database perusahaan. Dari database tersebut perusahaan akan mengakumulasi jumlah pendapatan dari masing-masing driver dan driver hanya perlu mengkonfirmasi jumlah tersebut.

Inland Revenue Authority of Singapore mengatur bahwa taxable income dari masingmasing driver ialah sebesar $40 \%$ dari gross income atau gross income dikurangi dengan beban yang benar-benar dikeluarkan oleh driver. Tarif yang diberlakukan oleh IRAS untuk pajak 
penghasilan driver ialah sebesar 20-22\%, tergantung besarnya pendapatan kena pajak masingmasing driver.

c. Pajak Tidak Langsung

Value-added tax atau PPN yang diberlakukan di Singapura berkaitan dengan jasa layanan transportasi online disebut Goods and Services Tax (GST). Tarif yang diberlakukan atas peraturan ini ialah sebesar 7\%. Menurut IRAS (Inland Revenue Authority of Singapore), subjek pajak dari GST ialah termasuk layanan digital, yaitu jasa melalui internet atau jaringan elektronik yang menyebabkan minimalnya intervensi manusia dalam proses penyampaiannya. Termasuk dalam definisi ini perusahaan penyedia layanan transportasi online sebagai bagian dari model bisnis sharing economy.

d. Implementasi dan Tantangan

Pengimplementasian peraturan perpajakan baik terkait pajak langsung maupun pajak tidak langsung dapat dikatakan telah berjalan dengan efektif di Singapura dan belum ada masalah yang signifikan terkait pemotongan pajak pertambahan nilai atas perusahaan maupun pajak penghasilan untuk driver. Hal ini bisa jadi disebabkan oleh efektivitas dan kesederhanaan aturan pemotongan pajak yang diterapkan Inland Revenue Authority of Singapore kepada pihak penyedia jasa transportasi online di Singapura.

\section{Vietnam}

\section{a. Gambaran Umum}

Sebagai salah satu negara berkembang di Asia Tenggara, perkembangan industri teknologi informasi juga berkembang pesat di Vietnam, tidak terkecuali untuk jasa layanan transportasi online. Dalam laporan media lokal Tuoi Tre, pendapatan perusahaan teknologi berbasis transportasi online di Vietnam mencapai 500 juta dolar per tahun. Di Vietnam, pasar layanan jasa transportasi online masih dikuasai oleh Grab. Gojek yang merupakan perusahaan start up asal Indonesia juga telah melakukan ekspansi ke Vietnam dengan nama Go-Viet, namun belum mampu menyaingi popularitas Grab. Terdapat pula beberapa aplikasi lokal yang juga bersaing di industri ini, sebut saja FastGo, MVL, Aber, VATO, dan Mai Linh Bike.

b. Pajak Langsung

Pajak langsung yang diberlakukan atas jasa layanan transportasi online di Vietnam ialah berupa pajak penghasilan yang ditujukan kepada driver. Pajak penghasilan ini memiliki tarif sebesar 4,5\% untuk driver dengan penghasilan minimal VNĐ100 juta per tahun. Pada tanggal 26 Agustus 2019, perusahaan mulai menarik VNĐ60.000 per harinya untuk setiap driver yang diperkirakan akan mendapat penghasilan setidaknya VNĐ100 juta per tahun dengan asumsi perusahaan yang akan menyetorkan pajak tersebut kepada pemerintah. Namun akibat protes massal yang dilakukan oleh driver, kebijakan ini langsung dicabut keesokan harinya.

c. Pajak Tidak Langsung

Pajak pertambahan nilai (PPN) merupakan pajak tidak langsung penyedia jasa transportasi online yang dikenai atas perusahaan dengan tarif tetap sebesar 20\%. Tarif ini diberlakukan untuk perusahaan asing seperti Uber dan Grab dimana otoritas pajak dapat menentukan pendapatan perusahaan namun tidak bisa mengestimasi beban yang ditanggung oleh perusahaan. Pada 2018, Grab menyumbang pemasukan sebesar \$19 Juta kepada Pemerintah Vietnam atas pembayaran pajak sehubungan dengan layanan jasa yang mereka berikan.

d. Implementasi dan Tantangan

Implementasi atas peraturan PPN di Vietnam terbukti efektif dilihat dari jumlah pemasukan yang diterima oleh Pemerintah Vietnam dari penyedia layanan jasa transportasi online. Namun untuk pajak langsung berupa pajak penghasilan masih menimbulkan masalah berupa penolakan atas besaran pendapatan kena pajak yang ditetapkan. Berdasarkan peraturan yang ada, pendapatan sebesar VNĐ100 juta per tahun akan dikenai pajak sebesar 4,5\%. Hal 
ini dianggap memberatkan bagi sejumlah driver sehingga dilakukan protes kepada pemerintah untuk menaikkan besaran pendapatan kena pajak menjadi VNĐ150 juta per tahun untuk tarif yang sama.

\section{Malaysia}

a. Gambaran Umum

Pesatnya permintaan terhadap layanan transportasi online telah melahirkan raksasaraksasa baru di segmen tersebut, termasuk di Malaysia. Seperti sebagian besar negara-negara di Asia Teggara, pangsa pasar penyedia jasa transportasi online di Malaysia juga dikuasai oleh Grab, yang juga telah mengakuisisi Uber pada April 2018.

Pada 16 Agustus 2016, Otoritas angkutan Malaysia (SPAD) memulai proses amandemen peraturan angkutan darat guna mereformasi industri taksi di Malaysia. Aturan baru tersebut juga mencakup layanan transportasi online seperti Grab dan Uber. Grab yang mengawali sepak terjang bisnisnya di Malaysia tidak luput dari aturan tersebut. Dengan amandemen ini seluruh angkutan transportasi baik berbasis aplikasi ataupun konvensional akan memiliki hak dan kewajiban yang sama.

b. Pajak Langsung

Inland Revenue Board of Malaysia (IRBM) pada 31 Maret 2017 merilis pernyataan pers untuk mengklarifikasi bahwa pajak penghasilan individu yang dikenakan kepada pengemudi Uber dan GrabCar serupa dengan pajak yang dikenakan pada seseorang yang menjalankan bisnis, yaitu sebesar $10 \%$. Pajak penghasilan dikenakan atas laba bersih yang timbul dari aktivitas Uber atau GrabCar dan pendapatan lainnya seperti remunerasi bulanan yang diterima dari pekerjaan, jika ada.

Pengemudi Uber atau GrabCar dapat mengklaim beban apa pun yang terjadi seperti bahan bakar, tol, biaya promosi, perbaikan dan pemeliharaan kendaraan, dan biaya yang dibayarkan kepada operator terhadap pembayaran kotor yang diterima sebagai pengurang gross income untuk menentukan besarnya pendapatan kena pajak.

c. Pajak Tidak Langsung

Pajak tidak langsung berupa SST (Service dan Sales Tax) dikenakan atas perusahaan. SST merupakan jenis pajak yang menggantikan GST (Goods and Service Tax) terhitung 1 September 2018. Untuk tarif, besarnya fixed rate untuk penyedia jasa layanan transportasi online ialah sebesar $6 \%$.

d. Implementasi dan Tantangan

Sama seperti Singapura, pengimplementasian peraturan perpajakan baik terkait pajak langsung maupun pajak tidak langsung dapat dikatakan telah berjalan dengan efektif di Malaysia dan belum ada masalah yang signifikan terkait pemotongan pajak pertambahan nilai atas perusahaan maupun pajak penghasilan untuk driver. Walaupun terdapat peningkatan besaran tarif SST yang ditetapkan Pemerintah Malaysia, hal ini diharapkan tidak akan membawa pengaruh signifikan kepada driver karena usaha perusahaan untuk memberikan pendapatan tambahan tanpa menaikkan tarif jasa layanan kepada pelanggan.

\section{KESIMPULAN}

Berdasarkan uraian yang telah dijelaskan sebelumnya, penulis menyimpulkan bahwa pajak tidak langsung yang dikenakan atas perusahaan penyedia layanan transportasi online di empat negara yang dijadikan dasar perbandingan telah berjalan dengan efektif dan efisien sehingga dapat diterapkan di Indonesia dengan beberapa penyesuaian. Pajak tidak langsung terbukti dapat meningkatkan pendapatan pajak negara dari sector sharing ecomony. Namun demikian, bukan berarti tidak ada masalah yang akan muncul. Masalah yang diperkirakan oleh penulis akan muncul ialah berupa pengklasifikasian perusahaan penyedia layanan transportasi online, apakah perusahaan akan digolongkan sebagai 
perusahaan jasa atau perusahaan transportasi. Masalah pengklasifikasian ini menjadi penting apabila tarif yang dikenakan atas perusahaan jasa dan perusahaan transportasi memiliki besaran berbeda.

Lain halnya dengan pajak langsung. Penulis melihat pada pajak langsung, beberapa masalah berpotensi dapat mempengaruhi kebijakan perpajakan atas driver, antara lain penggolongan driver sebagai pegawai tetap, pegawai tidak tetap, pekerja lepas, dan lainnya. Perbedaan penggolongan ini akan mengakibatkan besaran tarif pajak yang berbeda pula. Selain itu, besarnya tarif pajak ini terkadang juga dianggap memberatkan bagi sebagian driver karena mereka mengaggap penghasilan yang mereka dapat hanya cukup untuk membiayai kebutuhan sehari-hari sehingga tidak perlu dipotong pajak.

Apabila pemerintah Indonesia hendak membuat peraturan eksplisit tentang besaran tarif pajak pengemudi jasa layanan online, penulis berharap besarnya nilai pajak yang akan dipotong tidak memberatkan bagi para driver.

Untuk pemotongan pajak sendiri, penulis menganggap metode yang lebih efektif adalah dengan membebankan pajak ke perusahaan dan perusahaan yang memotong pajak dari penghasilan driver, agar tidak terjadi keambiguan untuk para driver layanan jasa ini.

\section{DAFTAR PUSTAKA}

Dai, Yue "Daisy". 2019. Taxing the sharing economy and digital platforms. Tax Notes International. 95(6). 511

Inland Revenue Authority of Singapore (IRAS). 2019. FAQs on the 60\% deemed expenses tax deduction for chauffeured private-hire car (PHC) /taxi drivers. Diakses tanggal 11 Januari 2020. Dari iras.gov.sg

https://www.iras.gov.sg/irashome/uploadedFiles/IRASHome/Businesses/FAQs\%20on\%20tax\% 20deduction $\% 20 \mathrm{on} \% 20 \mathrm{deemed} \% 2060 \% 20$ expenses $\% 20$ for $\% 20 \mathrm{PHC} \_$taxi $\% 20 \mathrm{drivers}$.pdf

Jamie Chee. 2018. Malaysia introduces Sales and Service Tax (SST): What you need to know. Diakses tanggal 11 Januari 2020. Dari www.tmf-group.com : https://www.tmf-group.com/en/newsinsights/articles/2018/december/malaysia-introduces-sst/

Jejak Tekno. 2019. Pengguna Aplikasi Didi Bisa Pesan Jasa dari Perusahaan Saingan. Diakses tanggal 11 Januari 2020. Dari www.kumparan.com : https://kumparan.com/jejaktekno/penggunaaplikasi-didi-bisa-pesan-jasa-dari-perusahaan-saingan-1rTU5S8Kxrb

Kementerian Keuangan. 2019. APBN 2019. Diakses tanggal 10 Januari 2020. Dari www.kemenkeu.go.id : https://www.kemenkeu.go.id/apbn2019

Koran Sindo. 2017. Wih, Didi Chuxing Penguasa Transportasi Online China. Diakses tanggal 11 Januari 2020.

Dari economy.okezone.com https://economy.okezone.com/read/2017/05/23/320/1697804/wih-didi-chuxing-penguasatransportasi-online-china

Nurhidayah, F., \& Alkarim F., 2017. Domination of Transport Network Companies (TNCs) in Indonesia : An Indonesian Case. International Journal of Business Economics and Law, 12(3), 11-20

Republik Indonesia. 1945. Undang-Undang Dasar Negara Republik Indonesia tahun 1945

Van Dam, Nick H.M. 2017. The $4^{\text {th }}$ Industrial Revolution \& The Future of Jobs. $1^{\text {st }}$ Edition [E-reader Version]. Diakses tanggal 10 Januari 2020. Dari www.besthrcertification.org: https://www.besthrcertification.org/docs/the-4th-industrial-revolution-the-future-of-Jobs.pdf

Vietnamnews. 2019. Grab Drivers want to put brakes on tax. Diakses tanggal 11 januari 2019. Dari vietnamnews.vn : https://vietnamnews.vn/economy/535203/grab-drivers-want-to-put-the-brake 